\title{
“BATTLE FOR TAVRIA": A HISTORICAL REGION IN POLITICS AND IN THE MARKET OF GOODS AND SERVICES
}

\author{
Mykola HOMANYUK
}

\author{
Kherson State University, Ukraine \\ gomanuk@gmail.com
}

\begin{abstract}
This article deals with the process, and with the main factors and mechanisms contributing to the modification of mental boundaries among people on the South of Ukraine in regard to the definition of what was and is the South Ukrainian's historical region of Tavria/Tauride. A conclusion is drawn that in the social perception of this historical region has been more and more frequently perceived as divided into two separate ones. The mainland part of the region has been expanded and became known as Tavria, while Crimea became known mostly as Tauride. This process of diversification of Tavria/Tauride toponyms coming into the political discourse of both Ukraine and Russian Federation that might allow some political manipulation and even legitimization of aggression.
\end{abstract}

Key words: Tavria/Tauride, Crimea, social perception of historical regions, local identity.

DOI: https://doi.org/10.17721/2413-7154/2019.82.20-26

UDC: 911.3

Received: October 13, 2019.

Accepted: December 16, 2019.

\section{“БИТВА ЗА ТАВРІЮ": ІСТОРИЧНИЙ РЕГІОН У СВІТІ ПОЛІТИКИ ТА НА РИНКУ ТОВАРІВ ТА ПОСЛУГ}

\author{
Микола ГОМАНЮК \\ Херсонський державний університет, Україна \\ gomanuk@gmail.com
}

\begin{abstract}
Анотація: В статті йдеться мова про головні фактори та механізми, що впливають на модифікацію ментальних кордонів південно-українського історичного регіону Таврія/Таврида серед мешканців цього регіону. Розглянуто особливості формування цього історичного регіону у часи Російської імперії, коли запровадження Таврійської губернії мало на меті відродження геополітичної ідеї Візантійської імперії, за радянської доби, та у сучасний період української незалежності. Хронологію та просторову динаміку формування регіону розкрито шляхом виявлення назв населених пунктів, організацій та підприємств, спортивних команд, засобів масової інформації, публічних культурно-мистецьких заходів брендів і торгових марок тощо, етимологічно пов'язаних з назвами регіону (Таврія/Таврида). Визначено основні актори, залучені до конструювання регіональної ідентичності регіону у зазначені історичні періоди, а також фактори, які впливають на сучасне сприйняття меж регіону, зокрема відповідна топоніміка, а також ідеї, висвітлені у науковій та художній літературі, засобах масової інформації, політичному дискурсі. Публічне сприйняття меж та складу регіонів Таврія/Таврида, а також співвідношення між ними виявлено шляхом інтерв'ювання мешканців півдня України. Робиться висновок, що у соціальному прийнятті цей історичний регіон поступово всі більше розділяється на два окремих історичних регіони. Материкова його частина більше сприймається як Таврія. Спостерігається також значне розширення цього регіону у сприйнятті мешканців Півдня України. У той самий час Крим сприймається переважно як Таврида. Основними механізмами цієї диверсифікації $\epsilon$, по-перше, топонімічний процес (найменування та перейменування населених пунктів, державних та муніципальних установ, подій тощо, у тому числі в рамках декомунізації), а по-друге - ринок товарів та послуг через формування низки «таврійських» брендів. Цей процес топонімічної диверсифікації використовується у політичному дискурсі як в Україні, так і Російській Федерації, в тому числі з метою політичних маніпуляцій і навіть легітимації агресії.
\end{abstract}

Ключові слова: Таврія/Таврида, Крим, соціальна перцепція історичного регіону, локальна ідентичність. 


\section{Introduction}

In the summer of 2018 the Greek community of Crimea proposed to change the name of the Republic of Crimea into Republic of Crimea-Tauride. "Not just add to the name of Crimea, but, if possible, completely change the name into Tavria or Tauride". In such way, this idea was supported by some Internet commentators. In fact, proposals to make Tauride an official name of Crimea had been already expressed right after the annexation in 2014. However, a different, non-Crimean part of that same Tauride historical region conceptis present in the area situated north of the Isthmus of Perekop. That Tauride has its own administrative center, its mass media, its local identity and even its annually elected Beauty Queen.

\section{Literature Review}

The physical borders of Tauride as an Ukrainian historical and geographical (ethnographical) region have been defined in many instances by various geographers and historians. The atlases of Ukraine, as for example the one under the editorship of Marchenko L. or Rudenko K. $[12,18]$, the definitions in various dictionaries (Volobuyev O., Golubev A., Yanko M.) [2, 6, 22], the monographic works (Goloborodko Y., Zastavnyy F.) $[5,13]$ which are all unanimous about the location and geographical boundaries of Tauride.

However, very different geographic borders and relative description of the respective local identities of Tauride are now fully shown in the very recent works of Gnatiuk O., Mezentseva N. and Mezentsev K. [4, 17].

\section{Goals}

The article focuses on defining the modifications in the perception of what would be the historical region of Tavria/Tauride and its current nature. This article reveals some factors and mechanisms of this process, as well as various aspects of its involvement into economic, political and cultural processes in Ukraine and Russian Federation.

\section{Results and discussion}

The historical region of Tavria/Tauride is often related to the Tavria region (a Russian Empire's Governorate since 1802), which was created in 1784 on the territory of the Crimean Khanate annexed to the Russian Empire within the so called "Greek project". That was a geopolitical project of the Russian Empire presenting itself as a renovation of the ideas of the Byzantine Empire. This "Greek project" was of course justifying and supporting the expansion of Russian Empire to the south. Due to that project, the south of contemporary Ukraine from Ovidiopol to Mariupol and from Sevastopol to Nikopol is full of settlements with Greek names.

(C) Mykola Homanyuk
This might explain why a new administrative and territorial entity, created on conquered land, might bear a name taken from the works of Herodotus. That Russian Empire Tauride province included two subregions: Crimea and Northern Tauride (nowadays the latter is part of Zaporizhzhia and Kherson oblasts) with the administrative center in Simferopol. These borders and notions of what were the geographical boundaries of Tavria/Tauride region are present and confirmed in the later Ukrainian maps.

The process of the formation of different borders of Tauride region and the displacement of its center to the Northern subregion started in the second half of $20^{\text {th }}$ century. This is confirmed by many evident examples. First of all, new names of settlements with Tavria/Tauride root appeared from 1952 to 2016 in Zaporizhzhia and Kherson regions. As a result, twenty settlements with the Tavria/Tauride root names exist nowadays such as: Tavriysk, Tavriyske, Tavria, Tavrychanka etc. However, three villages named in this manner and located on the right bank of Dnipro river territory have never been part of Tauride province of Russian Empire.

Second of all, there is an abundance of pragmatonymy (the names of organizations, goods and other results of human activity) employing the word "Tavria" in the region. The majority of it is observed in Kherson oblast. The most significant of them are Tavria cognacs, the passenger carrier company "Tavria lines", theatre festival "Melpomene of Tavria", the Beauty Queen Contest "Miss Tavria". There are also many dozens of names of companies, schools, public organizations, hotels, newspapers, sport clubs, contests, products, i.e. "Tavria pigs" (Skadovsk) and the "Tavria" cake baked at Kherson bread-baking plant.

Zaporizhzhia region is famous for its vehicle Tavria and the festival "Tavria trumpets" in Melitopol. The pragmatonymy of Tavria is also observed outside of the former Tavria governorate. There is a chain of "Tavria-B" malls in Odessa, a company "Tavria Clinker", the shipping company "Tavria Line" from Dnipro, the recreation center "Tavria" in Mykolaiv region, the "Tavria Meteorite" candies produced in Mykolaiv and others. Kherson, Mykolaiv, Odessa, Zaporizhzhia (administrative centers of oblasts) are moreover connected by the passenger train called “Tavria” Nr. 318/317.

Also, a new perception of what would be the geographical borders of Tavria area has been presented and expressed in many maps, atlases, articles, webpages and museum exhibitions starting from the year 2000. Those atlases indicated a Tavria region comprising some Black Sea and Azov Sea regions of Zaporizhzhia, Kherson and even Donetsk oblasts, as parts of it. At the same time, Crimea was indicated as a separate region $[3,12]$.

Media projects contributed to such perception. For example, the authors of the media project "Ukraïner" consisting in video documentaries about some Ukrainian regions, travelled in 2018 to the South of Ukraine, where they made a documentary video called Tavria. The authors of "Ukraïner" project considered that Tavria region comprised only the Dnipro river left bank areas 
of Kherson region and Kherson municipality on the Dnipro right bank.

On the other hand, geographer I. Pylypenko declared that the left bank areas of Kherson and some of the western parts of Zaporizhzhia region are geographically divided by a north-south line running from Vasylivka to Melitopol. Therefore, he proposes the new geographical definition of a "Tavria peninsula" into common use [7].

The perception among Ukrainians of where is the center of Tavria has gradually shifted to the city of Kherson. The majority of legal entities named with Tavria/Tauride rootare accumulated here [4], the most significant mass events are held here, the majority of products with "Tavria" labels are produced here and the majority of verses and songs glorifying Tavria region have been written here.

This is my Kherson, the beauty of the steppe,

This is my Kherson on the Dnieper bank,

This is my Kherson, I am with you forever,

This is the capital of my Tavria (Sorokin O.)

Market products have been named using Tavria root names as it became evident that it could increase products status by introducing them into a wider historical and geographical context.
In 2013, the slogan "Kherson is the capital of Tavria" was proclaimed by local authorities. It was initially seen on the billboards in Kherson and later in 2014 it was written in the official website of Kherson municipality [21]. Kherson is also the center of religious, administrative and territorial entities bearing the name of Tavria. For example, Kherson bishopric of the Ukrainian Orthodox Church and of the Ukrainian Orthodox Church of Kyiv Patriarchy assign a title of "Bishop of Kherson and Tavria regions" to their ruling Bishops.Also,the Tavria bishopric of the Ukrainian Autocephalous Orthodox Church, and the Tavria diocese of the Ukrainian Lutheran Church use the same formulation.

In 2016, the decommunization campaign in Ukraine led to emergence of new names for five settlements with "Tavria" names in Zaporizhzhia and Kherson regions. As a result of this process, there is the following toponymical situation in the South of Ukraine, which gives us the opportunity to observe the extent of adoption of Tavria root based toponyms.

At the same time the residents of South of Ukraine have not formed a precise opinion of neither what would be the center of Tavria/Tauride region nor of its boundaries. A number of focus-group researches and individual interviews revealed a wide range of very

Chart 1. Localization of the settlements with Tavria root based names in Ukraine. To the date of July 1, 2017 [1]

\begin{tabular}{|c|c|c|c|c|c|c|c|}
\hline \multirow[b]{2}{*}{ Name of the settlement } & \multicolumn{7}{|c|}{ Administrative territorial entity } \\
\hline & 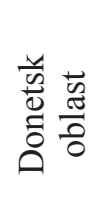 & 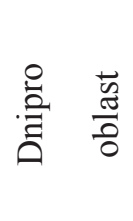 & 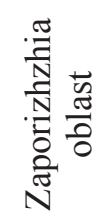 & 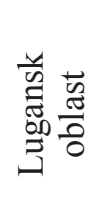 & 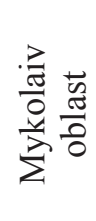 & 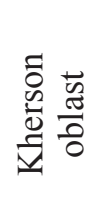 & 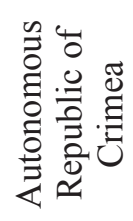 \\
\hline Tavrychanka & & & & & & 1 & \\
\hline Tavrychanske & & & & 1 & & & \\
\hline Tavrycheske & 1 & & & & & & $1 * * * *$ \\
\hline Tavriysk* & & & 1 & & & 1 & \\
\hline Tavriyske & & 1 & 3 & & & 5 & \\
\hline Tavria & & & 2 & & & 1 & \\
\hline Novotavrycheske & & & 1 & & & & \\
\hline Pokrovka-Tavria** & & & & & 1 & & \\
\hline Nova Tavria*** & 1 & & & & & & \\
\hline Total toponyms & 2 & 1 & 7 & 1 & 1 & 8 & 1 \\
\hline
\end{tabular}

* Town in Kherson oblast and a railway station in Zaporizhzhia oblast

** Postal name. There are two villages called Pokrovka in Ochakiv district of Mykolaiv oblast. In order not to confuse them, Pokrovka located on the Kinburnski peninsula is decided to be indicated as Pokrovka-Tavria on the postal correspondence.

*** This settlement is not in the list of the Ukrainian settlements, but it may be seen at web-sites news. Nova Tavria is located in Novoazovskiy district of Donetsk oblast

**** The maps and the majority of sources indicate it as "Tavricheske" though the list of settlements indicate it as "Tavriyske"

**** It was also planned to rename two settlements in Zaporizhzhia region, and namely to change the name of Kuybyshevo and Kirovo of Orekhovskiy district to Tavriyske [20] 
different opinions. A part of the population thinks that Tavria is the whole South of Ukraine; others consider instead Tavria as consisting in some Kherson districts attached to Crimea peninsula. Here are some

individual views:

- "What are the borders of Tavria? For me it is obviously Odessa, Mykolaiv and Kherson regions, let's say some parts of these regions. Tavria obviously includes Crimea also. The North of Crimea is of course Tavria" (male, 48 years old, Kherson).

- "Tavria for me is Crimea and somewhere from Odessa to Zaporizhzhia, in that direction, towards the Azov Sea, I mean, these three regions and Crimea. Tavria is Mykolaiv, Kherson, Zaporizhzhia and perhaps, partially Odessa, though Odessa is not all a part of Tavria" (male, 50 years old, Chaplynka).

- "Tavria is Crimea, the whole Kherson, and Dnepropetrovsk regions, even a part of Zaporizhzhia region, a part of Mykolaiv region till the Southern Bug river." (male, 60 years old, Kherson region).

- "Tavria is our Kherson region. I am not a historian, I do not know but I think that this is the territory of this side of the Dnieper until Crimea, I think so" (male, 56 years old, Kalanchak).

- "Tavria is a name of the place where we are now. The Chaplynka district, I think Kakhovka district is also Tavria, maybe Novotroitskiy district as well" (female, 37 years old, Chaplynka).

Some respondents consider that Tavria and Tauride are actually variants of the same name, others think that Tavria is related more to the mainland steppe part of Ukraine and Tauride instead describes Crimea. Also, Tavria and Tavria steppe for a part of respondents are not only names of their native region but are also a part of their identity, though not a primary one.

It is very important to understand the process of "Tavria/Tauride" toponym evolution and content change in the context of its distribution in Crimea, and in a historical perspective.

The Soviet Socialist Republic of Tauride was established in 1918 in Crimea, where it existed for more than a month. The central Museum of Tauride, i.e. the main local history museum of Crimea in Simferopol city, was established in 1921. In 1945, Soviet authorities created a Tavria military district in the South of Ukraine, comprising Kherson and Zaporizhzhia regions and Crimea. This denomination was used until 1956. The headquarters of this military district were established in Simferopol.

Later in ' 63 a soccer club previously called "AvantGarde" was renamed as "Tavria". Then, in the "70s a number of cultural and touristic entities in Crimea were given names including the word "Tavria": well known vocal and choreography ensemble "Tavria" (1971), a lot of hotels, guest houses called "Tavria" and "Tauride", and a several of newspapers and periodicals which were established at that time. In 1971, the publishing house "Crimea" was renamed "Tavria".

From the Soviet period to 1991-2004 period both the different variants of "Tavria" and "Tauride"were used in Crimea together with also the relevant adjectives corresponding to these names, "Tavriyskiy" and "Tavricheskiy".

The use of the name "Tavria/Tauride" in Crimea has however totally changed in 2018. Both Tavricheskaya Academy and Tavricheskiy College were established in that year, while the national television and broadcasting company (formerly named "Crimea") was renamed as "Tauride". Also, the name "Tauride" and an adjective "Tavricheskiy" were introduced into the names of main infrastructure objects, such as the "Tauride" highway, which connects Kerch bridge with Sevastopol, and the Tavricheskaya power-station. The ballots for the socalled referendum for the status of Crimea were published by a publishing house called "Tauride" (currently run as a State enterprise), while the publishing house called "Tavria" became bankrupt.

A number of private entrepreneurs followed this trend as well, as in the case of the future "People's" mayor of Sevastopol O. Chalyy, who created a company called "Tauride Electric". A private security company called "Tauride-Shield" provides its services to some strategic companies like "Crimean Post", "Black Sea Oil and Gas", "Crimean Water" etc. Sometimes, a new name of "Taurica" may also be seen as used inoccupied Crimea, but it is not so popular as Tavria or Tauride.

The borders between Tavria and Tauride regions are however neatly perceived and well defined by the residents of Crimea and Ukraine mainland, at least according to the following examples: the local newspaper of the northernmost city of Crimea, Armiansk, is called "The Northern Tauride". That of course would mean that Tauride's border ends at Isthmus of Perekop. According to this newspaper name, the land situated on the other side of this isthmus would not be Tauride. At the same time the name of Chaplynka district (rayon) local newspaper is "Tavria's Voice" (former "Soviet Tavria"). This mainland Ukraine district lays on the land north of Perekop.

As to the perception of ordinary Crimean peopleit is worth saying that the denotations of Tavria and Tauride are not clearly defined. Though for the majority of the Crimean population Crimea and Tauride are geographical synonyms, there are different variant of what does "Tavria" mean:

- "I talked to a woman from Krasnoperekopsk in a sanatorium, she said that Tavria is Crimea and part of Kherson region"(female, 68 years old, Gurzuf).

- "I think that Tavria ends where the steppe ends. It is Kherson, perhaps part of Mykolaiv. Till Donbass in the East, maybe. Almost to Mariupol, and till Kharkov in the North, or to the Dnieper river, perhaps. Till Crimea in the South. Because Crimea is Tauride, the mountains. For me Tavria is something steppe, sunny, warm" (male, 41 years old, Yevpatoria).

Toponymy issues have become political subjects after the annexation of Crimea. In 2014, the Tavricheskiy Muftiate was created as a counterbalance to the Religion Administration of Muslims of Crimea. 
Right after the so-called referendum on $16^{\text {th }}$ of March 2014, a member of State Duma of Russia M. Degtiarev proposed to rename Crimea Republic as the Republic of Crimea-Tauride [9]. In January of 2015 another Russian politician V. Zhyrinovskiy proposed to officially rename Crimea as Tauride [11] and explained it as justified by the necessity to return to a "primordial" name, unlike the later "Crimea" adopted under Crimean-Tatars domination.

The same idea was announced later by a Chairman of the Greek national and cultural community "Tauride" I. Shonus, who proposed a compromise with the double name of "Crimea-Tauride" and appealed to "historical justice": "There are such precedents, such as the Northern Ossetia (Alania), Yakutia (Sakha). Why can't we render historical justice to this land and name it "Republic of Crimea-Tauride?" [8]. In 2019, this proposal was supported by the so-called vice-premierminister of Crimea, G. Muradov.

According to a member of Ukrainian Institute of National Memory M. Mayorov "The idea of reincarnation of Tauride governorate within its former borders may unexpectedly be implemented just like it happened with "Novorossia" in 2014. The urgency of such schedule is vivid, the control over the mainland of Tavria may solve the problem of water supply to Crimea, since the water of the Northern-Crimean Canal flows along these lands"[16].

V. Putin signed a graffiti "Everything will be Tauride" during his visit to the Crimean Youth Education Forum in 2016. Some internet users interpreted it as a hint of further plans of annexation of more Ukrainian territory. "What is Tauride, comrades?! Let's have a look at the map. Here it is. Crimea plus the mainland from Ochakiv through Kherson and till Berdyansk. It is but a step from Mariupol. All know that Putin means what he says. Tauride governorate. Let it be!" [3] - an example of relevant opinions.

The then leader of the so-called Donetsk People's Republic A. Zakharchenko also said about Tauride: "You know that our ancestors drew a map for us. Kharkov and Tauride are indicated there. We are going to expand it a little bit. We may also need Bessarabia", he said during the meeting in occupied Donetsk in February 2018 [19].

Conclusion. Between the end of XVIII and the beginning of the $\mathrm{XX}$ centuries the area of the historic region of Tavria/Tauride comprised the Northern Tavria (lower left bank of the Dnieper and a part of the Northern Transazov) and the Crimean Peninsula with its center in Simferopol.

During that period, the names of Tavria and Tauride were purely synonyms. In the second half of the XX century a gradual differentiation of toponyms Tavria and Tauride was initiated. The two variants were still synonyms but, while the name of Tavria was more applicable to the Northern Tavria and the whole steppe area, instead the name of Tauride was applicable only to Crimea.

A gap between Tavria and Tauride toponyms got wider since 1991. Gradually a new perception of the center of the Tavria region as Kherson emerged.

The data presented here confirms that the symbolic and information space of the South of Ukraine has actively enriched with Tavria toponyms. The geography of its distribution wentfar outside of the historic area of Tavria/Tauride till Odessa and Novoazovsk. Tavria toponymy and pragmatonymy has been observed as becoming prevalent on the whole territory of Kherson region, in Crimea and in the part of Zaporizhzhia region.

The toponym Tavria/Tauride have separated into two paronymous words, namely Tavria and Tauride. The name of Tavria is applicable to Ukraine mainland (Zaporizhzhia, Mykolaiv, Kherson, partially Odessa, Dnipropetrovsk and Donetsk oblasts), and Tauride is applicable to Crimean Peninsula.

The processes of the appearance of two distinct toponyms (Tavria and Tauride) was occurred because of two mechanism. The first mechanism implies renaming of the settlements, the state and municipal entities, mass events etc. The second mechanism was initiated by the market of goods and services. This mechanism was brought the creation and promotion of "Tavria" brands to the market and its identity support. It is obvious that due to the second mechanism Tavria name expands into the mainland of Ukraine and forms new identities.

This process of diversification of Tavria/Tauride toponyms coming into the political discourse of both Ukraine and Russian Federation that might allow some political manipulation and even legitimization of aggression.

\section{References:}

1. Alfavitnij pokažčik naselenih punktìv Ukraïni [Alphabetical index of settlements of Ukraine]. Retrieved from: http://static.rada.gov.ua/zakon/new/NEWSAIT/ADM/zmist.html (In Ukrainian).

2. Volobuyev O. V. Tavrika. In: Sovetskaâ istoričeskaâ ènciklopediâ [Soviet Historical Encyclopedia], 1973, Vol. 19, p. 19. (In Russian).

3. Vse budet Tavrida [Everything will be Tauride]. Retrieved from: http://rusdozor.ru/2016/08/20/vsyo-budettavrida/ (In Russian).

4. Gnatiuk O. M. Nazvi pìdpriêmstv ta organìzacìj Ukraïni âk marker teritorìal'noï ìdentičnostì naselennâ [Names of enterprises and organizations of Ukraine as a marker of territorial identity of the population]. Kï̈vs'kij geografičnij ŝričnik [Kyiv Geographical Yearbook], 2014, vol. 9, pp. 67-77. (In Ukrainian).

5. HoloborodkoYa. Yu. Pivdennij areal. Konsorcium literaturnoï Tavriï [Southern area: Consortium of Literature Tavria]. Kyiv: Fakt, 2007, 400 p. (In Ukrainian).

6. Golubev A. V. Severnaâ Tavriâ [North Tavria]. In: Sovetskaâ istoričeskaâ ènciklopediâ [Soviet Historical Encyclopedia], 1969, Vol. 12, pp. 654-655. (In Russian). 
7. Homanyuk M., Pylypenko O. Geografičnì ta socìologičnì peredumovi verifíkaciï [Tavria Peninsula: Geographical and sociological precondions of verification]. In: Vid geografiï do geografičnogo ukraïnoznavstva: evolûciâ osvitn'o-naukovih idej ta pošukìv [From geography to geographic Ukrainian studies: evolution of educational and scientific ideas and investigations]. Chernivtsi: Chernivtsi National University, 2016, pp. 16-17. (In Ukrainian).

8. Greki predlagaût izmenit' nazvanie Kryma [Greeks are offering to change the name of Crimea]. Retrieved from: crimea.ria.ru/society/20180613/1114626404.html (In Russian).

9. Deputaty predlagaût vernut' Krymu istoričeskoe nazvanie «Tavrida» [The deputies suggest returning the historical name "Tauride" to Crimea]. Retrieved from: http://www.aif.ru/politics/russia/1128087 [in Russian].

10. Etnografičnì regioni Ukraïni [Ethnographic regions of Ukraine]. Retrieved from: https://ua.igotoworld.com/ en/article/953_etnograficheskie-regiony-ukrainy.htm (In Ukrainian).

11. Žirinovskij potreboval vernut' Krymu nazvanie Tavrida [Zhirinovsky demanded to return the name of Tauride to Crimea]. Retrieved from http://gordonua.com/news/crimea/ZHirinovskiy-potreboval-vernut-Krymu-nazvanieTavrida-59736.html (In Russian).

12. Marchenko L (ed.). Zagal'nogeografičnij atlas Ukraïni [General geographic atlas of Ukraine]. Kyiv: Cartographia, 2001, 112 p. (In Ukrainian).

13. Zastavnyy F. D. Ukraïns'kì etničnì zemlì [Ukrainian Ethnic Lands]. Lviv: Svit, 1993, 176 p. (In Ukrainian).

14. Zorin A. Kormâ dvuglavogo orla... Russkaâ literatura i gosudarstvennaâ ideologiâ poslednej treti XVIII pervoj treti XIX stoletiâ [Feeding the double-headed eagle ... The Russian literature and state ideology of the last third of XVIII - the first third of XIX century]. Moscow: New literary review, 2001 (In Russian).

15. Krovec': Mereževij atlas narodnogo mistectva [Krovets': Network atlas of folk art]. Retrieved from: https:// krovets.com.ua/uk/ (In Ukrainian).

16. Mayorov M. Krymskij most, Dneprovskaâ voda i ošibka kartografa Rittiha [Crimean bridge, Dnieper water and the cartographer Rittikh's mistake]. Retrieved from: https://petrimazepa.com/krymskii_most_dneprovskaa voda_i_osibka_kartografa_rittiha (In Russian).

17. Mezentseva N., Mezentsev K. Percepcìnì portreti regìonìv Ukraïni [Perceptual portraits of the regions of Ukraine]. In: Regìnal'nì problemi Ukrä̈ni: geografičnij analìz ta pošuk šlâhìv virišennâ [Regional problems of Ukraine: geographic analysis and the search for solutions], Kherson: Vyshemyrskyi, 2005, pp. 208-213 [in Ukrainian].

18. Rudenko L. (ed.). Politiko-administrativnij atlas Ukraïni [Political and administrative atlas of Ukraine]. Kyiv: Kartohrafija, 2006, 120p. (In Ukrainian).

19. «Predki narisovali nam kartu - Har'kov, Tavrida. Bessarabiâ nam eŝe, navernoe, nužna», - glavar' «DNR» Zaharčenko o novyh planah zavoevanij [The ancestors drew a map for us... Leader «DPR» Zakharchenko about new conquest plans]. Website Censor. Net. Retrieved from: https://censor.net.ua/news/3050082/predki_narisovali_nam_ kartu_harkov_tavrida_bessarabiya_nam_esche_navernoe_nujna_glavar_dnr_zaharchenko (In Ukrainian).

20. Proces perejmenuvannâ naselenih punktìv oblastì rušiv / Oficìjnij vebsajt Zaporìz'koï oblasnoï deržavnoi administraciï [The process of renaming of the settlements of the region has started. Official site of Zaporizhzhia state regional administration]. Retrieved from: http://www.zoda.gov.ua/news/29345/protses-pereymenuvannya-naselenihpunktiv-oblasti-rushiv.html (In Ukrainian).

21. Herson - stolicâ Tavriï [Kherson is the capital of Tavria]. Retrieved from: http://www.city.kherson.ua/news_ detail/herson-stolicya-tavriyi [in Ukrainian].

22. Yanko M. T. Toponimičnij slovnik-dovidnik Ukraïns'koï SSR [Toponymic Dictionary of Ukrainian SSR]: Kyiv: Radyans'ka shkola, 1973, 180 pp. (In Ukrainian).

\section{Список використаних джерел:}

1. Алфавітний покажчик населених пунктів України. - Режим доступу: http:/static.rada.gov.ua/zakon/new/ NEWSAIT/ADM/zmist.html

2. Волобуев О. В. Таврика / О. В. Волобуев / Советская историческая энциклопедия. - 1973. - Вып.19. - C. 19.

3. Все будет Таврида. Режим доступу: http://rusdozor.ru/2016/08/20/vsyo-budet-tavrida/

4. Гнатюк О. М. Назви підприємств та організацій України як маркер територіальної ідентичності населення / О. М. Гнатюк // Київський географічний щорічник. - 2014. - Вип. 9. - С. 67-77.

5. Голобородько Я. Ю. Південний ареал. Консорціум літературної Таврії / Я. Ю. Голобородько. - К.: Факт, 2007. $-400 \mathrm{c}$.

6. Голубев А. В. Северная Таврия / А. В. Голубев / Советская историческая энциклопедия. - 1969. - Вып. 12. - С. 654-655.

7. Гоманюк М. Півострів Таврія: Географічні та соціологічні передумови верифікації / М. Гоманюк, I. Пилипенко // Від географії до географічного українознавства: еволюція освітньо-наукових ідей та пошуків. - Чернівці: ЧНУ, 2016. - С. 16-17.

8. Греки предлагают изменить название Крыма. - Режим доступа: crimea.ria.ru/society/20180613/ 1114626404.html 
9. Депутаты предлагают вернуть Крыму историческое название «Таврида». - Режим доступа: http://www. aif.ru/politics/russia/1128087.

10. Етнографічнірегіони України.-Режимдоступу:https:/ua.igotoworld.com/en/article/953_etnograficheskieregiony-ukrainy.htm

11. Жириновский потребовал вернуть Крыму название Таврида. - Режим доступа: http://gordonua.com/ news/crimea/Zhirinovskiy-potreboval-vernut-Krymu-nazvanie-Tavrida-59736.html

12. Марченко Л. Загальногеографічний атлас України / Л. Марченко (ред.). - К.: ДНВП «Картографія», 2001. $-112 \mathrm{c}$.

13. Заставний Ф. Д. Українські етнічні землі / Ф. Д. Заставний. - Львів: Світ, 1993. - 176 с.

14. Зорин А. Кормя двуглавого орла... Русская литература и государственная идеология последней трети XVIII - первой трети XIX столетия / А. Зорин. - М.: Новое литературное обозрение, 2001.

15. Кровець: Мережевий атлас народного мистецтва. - Режим доступу: https://krovets.com.ua/uk/

16. Майоров М. Крымский мост, Днепровская вода и ошибка картографа Риттиха. Режим доступа: https:// petrimazepa.com/krymskii_most_dneprovskaa_voda_i_osibka_kartografa_rittiha.

17. Мезенцева Н. Перцепційні портрети регіонів України / Н. Мезенцева, К. Мезенцев / Регіональні проблеми України: географічний аналіз та пошук шляхів вирішення. - Херсон: Вишемирський, 2005. - C. 208-213.

18. Руденко Л. Політико-адміністративний атлас України / Л. Руденко (ред.). - К.: ДНВП «Картографія», 2006. $-120 \mathrm{c}$.

19. «Предки нарисовали нам карту - Харьков, Таврида. Бессарабия нам еще, наверное, нужна», - главарь «ДНР» Захарченко о новых планах завоеваний / Вебсайт Censor. Net. Режим доступа: https://censor.net.ua/ news/3050082/predki_narisovali_nam_kartu_harkov_tavrida_bessarabiya_nam_esche_navernoe_nujna_glavar_ dnr_zaharchenko

20. Процес перейменування населених пунктів області рушив / Офіційний вебсайт Запорізької обласної державної адміністрації. - Режим доступу: http://www.zoda.gov.ua/news/29345/protses-pereymenuvannyanaselenih-punktiv-oblasti-rushiv.html

21. Херсон - столиця Таврії. Режим доступу: http://www.city.kherson.ua/news_detail/herson-stolicya-tavriyi

22. Янко М. Т. Топонімічний словник-довідник Української ССР / Т. М. Янко (ред.). - К.: Радянська школа, 1973. $-180 \mathrm{c}$. 